\title{
What Can Feminism Offer Student Leadership Education?
}

\author{
Susan V. Iverson \\ Professor, Higher Education Leadership \\ Manhattanville College \\ Brenda L. McKenzie \\ Senior Lecturer, Higher Education Administration \\ Vanderbilt University \\ Malina Halman \\ Assistant Director, Office of Academic Services \\ Vanderbilt University
}

\begin{abstract}
Given societal calls for transformational leadership that will lift people to higher levels of motivation and critical consciousness, this paper critiques existing student leadership education efforts and proposes that leadership educators adopt core tenets of feminism in order to prepare students to be engaged, change-oriented leaders in their communities. Today's literature on student leadership development places an over-emphasis on positional leadership, technical problems, and leadership competencies. Feminism can serve as a theoretical strategy for addressing these problems by considering the complexities of identity, re-conceptualizing power, amplifying student voice, and encouraging activism. In particular, we argue that consciousnessraising is essential for leadership development and offer ways in which it can be employed within leadership curriculum, among student leaders, and among leadership educators.
\end{abstract}

\section{Introduction}

Contemporary challenges facing society call for transformative leadership; that is, the capacity to impact people and events in profound ways that raise all to higher levels of motivation and critical consciousness. Such transforming leaders are essential to initiate and realize needed organizational and social change (Astin \& Astin, 2000; Burns, 1978; Dugan, 2017; Roberts, 2007). Yet, for the volumes written about leadership, gaps and critiques exist in how to actualize transformational leadership and to develop transforming leaders. Additionally many student leadership education approaches still "rely on leadership fads, reductionistic platitudes, and nondevelopmental approaches" (Owen, 2015, p. 8). In this paper, we illuminate what we believe are particular gaps in existing student leadership education efforts. We then advance this conversation by asking (and discussing) the question: "What might be gained by bringing a feminist lens to the work of student leadership education?" We propose that leadership educators purposefully adopt the tenets of feminism in order to prepare students to be critically engaged and change-oriented leaders in their environments. We posit that educators can use feminism to 1) illuminate how identity matters, 2) design leadership activities that encourage shared power, 3) raise consciousness and help students find their voice, and 4) spur students to become activists. 


\section{The Problem(s)}

The literature on leadership is voluminous; yet, debate and limitations exist. In this section, we discuss a few problems we observe in the dominant thinking about leadership as preface to our argument that feminist theory is a lens for responding to these problems.

Over-Emphasis on Positional Leadership. Theories of leadership tend to overemphasize positional leadership. This is evident when reviewing the literature on leadership, which we cluster into three categories (see Chemers, 1997; Kezar, Carducci, \& ContrerasMcGavin, 2006; Northouse, 2016 for full discussion of these theories):

- $\quad$ Dispositional theories: certain attributes make a great leader (e.g., "great man" theories that assert leadership is an innate ability, trait theories that delineate universal traits common to all leaders).

- $\quad$ Behavioral theories: great leadership is based on what someone does; key behavioral patterns result in leadership, and thus leadership capabilities can be learned, rather than being inherent.

- $\quad$ Contingency theories: an individual's ability to lead is contingent upon various situational factors, including the leader's preferred style, and the capabilities and behaviors of followers.

Burns' (1978) theorizing of transforming leadership as a process, not a position, laid the foundation for contemporary theories that describe how leadership is relational, shared, collaborative, and seeks to bring about positive social change. Yet, Burns' work is too often misrepresented as transformational, meaning a characteristic (dispositional or behavioral) that a person possesses (Bass, 1985; Dugan, 2017; Northouse, 2016). The focus then is on leadership as an aggregation of conditions -- leader attributes, behaviors, situational factors; and leaders risk approaching organizational challenges in technical ways, or, as Heifetz (1994) posited, in maladaptive ways.

Over-Emphasis on Technical Problems. According to Heifetz (1994), leaders are confronted by two types of problems -- technical and adaptive. Technical problems have known solutions and typically require technical expertise; leaders apply current knowledge, skills, and/or tools to resolve a situation (Heifetz, 1994, pp. 71-72). For instance, a technical problem could be handling a student's grievance of a course grade. The procedures to handle the problem are known, although the solution is not known (whether or not the student will receive an adjusted grade). With the second type of problem -- adaptive -- the problem definition is not clear-cut, and technical fixes are not available; the problem cannot be solved using one's existing knowledge and skills, thus requiring people to make a shift in their values, expectations, attitudes, or habits of behavior. Heifetz (1994) stated "adaptive work involves not only the assessment of reality but also the clarification of values" (p. 31). The recurrence of hazing incidents on college campuses is an example of just such an adaptive problem. Currently, much of the leadership exhibited addressing the issue of hazing revolves around the "easy" work or the quick fix. Chapters are suspended, task forces are established to examine the culture. Yet these do not get at the root problems to be resolved. Instead, we need to examine what is at the core of hazing incidents, e.g., power, control, and hypermasculinity, engage the community in critical 
reflection on how these underlying problems are deeply rooted in our practice, and implement actions that lead to structural change.

This capacity to do adaptive work is not easily developed. We argue that insufficient attention is given in the literature on student leadership education regarding how to equip students to use knowledge of leadership to create new responses to leadership situations that are not clear-cut. Current leadership education efforts can perpetuate the "same old way" of approaching situations. Decades ago, Conger (1991) critiqued an over-emphasis on strategy and rationality, and called instead for creative approaches that draw upon affect and imagination, and that complicate taken-for-granted assumptions about leadership. We argue that such perspectives need to be added to leadership education efforts.

The Downside of Competencies. A further shortcoming is that this difficult work of rethinking and reframing gets reduced to a prescriptive set of knowledge, skills, and abilities -competencies. Our discussion of the preceding two problems illuminates how competency-based education has continued to emerge as a panacea to leadership educators' challenges (Conger \& Ready, 2004; Hollenbeck, McCall, \& Silzer, 2006; Seemiller \& Murray, 2013). Whatever we may want leaders prepared to do gets converted to a set of competencies -- key knowledge, skills, and abilities necessary to be an effective leader (e.g. problem-solving, effective communication, tolerance for ambiguity). The use of competencies in leadership education can also provide for a common language, a benefit for a campus community where leadership education exists in multiple areas (Conger \& Ready, 2004). Yet, competency-based approaches to leadership education have their downside, including an over-emphasis on a narrow set of characteristics which are not universally effective (Bolden \& Gosling, 2006).

Competencies can be alluring. To the previous challenge, we could advance student leadership education for developing skills as an adaptive leader (e.g. problem solving, resilience, facilitation). Educators could create learning situations that allow students to confront contextualized, ill-structured problems and strive to find meaningful solutions (Iverson, 2007). However, too often, leaders are unwittingly prepared to (only) maintain the status quo (to address technical problems), rather than inspire creative thinking about how to identify and analyze intractable problems and how to mobilize adaptive work. The challenge, for developing leadership competencies, is how to develop people's adaptive capacity for tackling the complex problems that have no clear-cut solutions; knowing what to do when they don't know what to do (Heifetz, 1994).

Further, and this issue segues into the next challenge, leadership competency-based education tends not to consider the differential experiences of women and students of color (Debebe \& Reinert, 2014; McKenzie, 2014). As Eagly and Carli (2007) highlighted, "women are held to a higher standard of leadership competency than men" (p. 110), and competence may not have the same meaning for men and women. Because of these different standards, women face doubts about their leadership competence. Female leaders often have difficulty being heard and, if they assert their voice, are perceived as non-feminine and too aggressive (Rhode, 2016). However, male leaders who exhibit these same behaviors are perceived as assertive and successful (Eagly \& Carli, 2007). 
Limited Attention of Identities. As leadership educators are designing initiatives, including how to develop transforming student leaders, they tend to generalize leadership, failing to consider how dimensions of identity matter in the development and performance of leadership. Foremost among these is the identity of being a student. Very limited attention has been given to the development of frameworks for college student leadership. Dugan, Komives, and Segar (2008) found that most research on student leadership adopts leadership measures not constructed for the college population (p. 480).

More recently, some models have emerged that are specific to student leadership, e.g., the social change model of leadership (Komives, Wagner, \& Assoc., 2009), the relational leadership model (Komives, Lucas, \& McMahon, 2013), and the student leadership challenge (Kouzes \& Posner, 2008). Researchers have illuminated that students participating in leadership education demonstrate a stronger sense of self, improved decision-making skills, and growth in the development of modeling the way and enabling others to act (Cress, Astin, Zimmerman-Oster, \& Burkhardt, 2001; DiPaulo, 2008; Posner, 2009; Shertzer \& Schuh, 2004). Yet, some critique these generic models for their failure to disaggregate leadership identities, suggesting that leadership is accessible to everyone, "regardless of their social identities" (Tillapaugh, Mitchell Jr., \& Soria, 2017, p. 27).

Leadership identity development does not occur in isolation from other dimensions of identity (Debebe \& Reinert, 2014); yet, these intersections remain understudied. The scholarship on leadership has become more inclusive of women and has interrogated how gender matters to the development and enactment of leadership (Eddy, Ward, \& Khwaja, 2017; Storberg-Walker \& Haber-Curran, 2017). Yet, little scholarly attention has been specifically given to female college students, and even less explores how to prepare female college students for their leadership experiences in the world of work (McKenzie \& Iverson, 2017). Further, attention to other dimensions of identity, such as race, is limited (Rosser-Mims, 2010).

\section{Feminism and Leadership}

In this section, we explicate how feminism can serve as a theoretical strategy for addressing the problems described above. While we are referring to feminism as a unitary category, it is not a monolithic ideology. Numerous branches of feminist thought each offer a distinctive view and explanations for women's oppression (see Tong, 2016 for full discussion of distinctions and theoretical tensions). There exist, however, threads across feminist thinking and practice that serve as core tenets. We illuminate these core tenets and how these are useful for leadership development: identity matters; power; consciousness and voice; and activism.

Identity Matters. Feminism is a movement striving for the political, social, and educational equality of all genders. The basic assumptions undergirding feminism are that gender is central to the structure and organization of society; gender inequality exists; and gender inequality should be eliminated (Allan, 2008). Feminism is not a monolithic ideology (Tong, 2016); we align with those feminist scholars who challenge female essentialism, problematize gender binary language to acknowledge gender fluidity and trans* identities, and illuminate the complexities of intersecting identities, inclusive of race, sexuality, and social class among other 
dimensions of identity (Chin, Lott, Rice, \& Sanchez-Hucles, 2008; Debebe \& Reinert, 2014; Hesse-Biber, 2011; Spelman, 1998).

A feminist perspective on leadership must be considerate of the differential experiences of women and students of color (Debebe \& Reinert, 2014). We argue for critique of the assumption that all students gain leadership efficacy and capacity in the same way through the same educational approaches. Rather we must problematize the "dichotomous, false adversarial relationship" (Haber-Curran \& Tillapaugh, 2017, p. 17) that contributes to the continuation of the development of leadership theory as well as views of leadership that are male-normed (Madsen, 2017). Portrayals of leadership comprised of masculine characteristics (Fine, 2009), such as the grandiose images of transformative leaders, may leave some individuals feeling incapable of performing this seemingly heroic role (Iverson, Allan, \& Gordon, 2017). Student leadership education can play a critical role in understanding the role our socially constructed understanding of gender plays in one's leadership journey (Haber-Curran \& Tillapaugh, 2017, p. 11).

Broadening focus beyond positional leaders, the inclusion of readings from a variety of voices, including those of women and people of color, and challenging views of masculine versus feminine characteristics of leadership are just a few ways leadership educators can play this critical role (Haber-Curran \& Tillapaugh, 2017)

Reconceptualizing Power. A feminist perspective brings explicit attention to how power operates in relationships and organizations. A dominant conception of power is that it is exercised as power-over others through positional authority (Allen, 1998). A feminist lens enables disruption of this dominant notion of power-over (and the over-emphasis on positional authority), to advance alternative conceptions of "power as a productive force, rather than a primarily prohibitive or repressive one" (Allan, Gordon, \& Iverson, 2006, p. 44). Alternative conceptualizations emerge revealing power as shared and distributed, and as energy that is circulating and can be taken up by anyone whether that person has positional authority or not.

Leadership then, no longer held positionally, can be shared and "leadership functions are distributed among group members" (Drescher, Korsgaard, Welpe, Picot, \& Wigand, 2014, p. 772). This may result in shifts in language, too. Feminist scholars often redefine traditional terms associated with leadership (Batliwala, 2011; Chin, 2004; hooks, 1994); leaders are no longer solo architects, but instead leadership may be viewed as a "collective enterprise" (Astin \& Leland, 1991, p. 37), a "process" (p. 111), or a collaborative endeavor (Bensimon \& Neumann, 1993). Power is conceived as energy -- circulating, enabling leadership activities that empower others -- "in other words... power with others, or shared power" (Astin \& Leland, 1991, p. 8, emphasis in original). The focus is no longer on the individual leader, whose actions achieve a desired outcome or change; rather the individual is eclipsed by the group connecting to ideas advanced by connective leadership (Lipman-Bluman, 1992), which relies on the empowerment of others. College students need to understand that the concepts of power and leadership are not separate but are inextricably linked. Given that student leadership education efforts may not address power in relation to leadership much, if at all, these different conceptualizations of power should be incorporated as a way for college students to explore what power means to them. Inclusion of discussions about power and leadership become a necessary component, a way to shift conventional views of power-over to one of empowerment, a key foundation of a feminist approach to leadership. 
Raising Consciousness and Amplifying Voice. A feminist perspective on leadership allows us "to hear women's voices that long have been held in silence" (Thurber \& Zimmerman, 2002, p. 12). Thurber and Zimmerman identified that the use of voice can be: a) personal (feeling empowered and validated through self-reflection); b) collaborative (speaking and sharing with others); and c) public (becoming "agents for change rather than targets of change") (pp. 14-15). This use of voice is tied to the emancipatory emphasis in feminist leadership: a commitment to social justice, equity, and change for the betterment of all (Batliwala, 2011). While this attention to voice is evident in feminist literature and some scholarship on women and leadership (Dugan, Komives, \& Segar, 2008; Haber-Curran \& Sulpizio, 2017; Keohane, 2014), it is less (if not rarely) visible in extant literature on leadership. Of note, what we are describing here differs from studies that examine gender differences in communication styles (e.g., Klofstad, Anderson, \& Peters, 2012).

One example of how individuals' voices are silenced relates to the imposter phenomenon, a "strong belief that they are not intelligent; in fact, they are convinced that they have fooled anyone who thinks otherwise" (Clance \& Imes, 1978, p. 1; see also Ross, Stewart, Mugge, \& Fultz, 2001). Lack of belief in self is a trap that college students can find themselves facing. Studies such as McKenzie's (2015), illustrate the struggle female-identified students face between speaking up for what is right and deferring to others (typically males).

Through dialogue with others (e.g., consciousness-raising groups), students can feel empowered and validated. Consciousness-raising (CR) groups in particular, which blossomed in the late 1960s and early 1970s, are a powerful mechanism through which student leaders can frame their lived experiences through dialogic practices. By gathering and sharing their personal narratives, "CR functions as an ideal way for women to begin to see themselves as leaders, particularly because CR was designed to be a 'radicalizing' process, a way of inspiring women to take action" (Aleman \& Stephenson, 2012, p. 118). In these groups, students gain awareness, become empowered, and are a means through which to organize, strategize, and act (Aleman \& Stephenson, 2012).

Becoming Activists. Raised consciousness, amplified voices, and reconceptualized power as collective action -- these coalesce in feminisms' final tenet: activism. Applying a feminist approach to student leadership education emphasizes action and prepares students to be change-agents. Students are more likely to place emphasis on larger social issues and social responsibility and work toward adaptive change. Evidence of this can be found in many studentled political movements and organizations, such as the "I, Too, Am" Movements, the Occupy Movement, the \#MeToo Movement, and recent rallies and marches against gun violence (BauerWolf, 2018; Butler, 2014; Gautney, 2011; Gluckman, Read, Mangan, \& Quilantan, 2017).

Reconceptualizing leadership as collective action empowers students to instigate change. Individuals can enact change within the existing organizational structures, or they may adopt a more activist orientation as grassroots leaders (Kezar \& Lester, 2011; Meyerson \& Tompkins, 2007). We argue that student leadership education needs to re-examine what it means to be an activist and understand how today's college students could make their voices heard. After leadership educators gain this understanding, we can then work together to create opportunities with college students to use their voices to make positive change. Activism may be operating in 
more private settings, such as daily conversations or online discussions. Leadership educators can facilitate college students' use of social media as a way to "engage in less hierarchical activism and amplify the voices of people otherwise ignored by mainstream media outlets" (Linder, Myers, Riggle, \& Lacy, 2016, p. 223). Resonating with the feminist adage, the personal is political, leadership educators can support students to be agents of change; to transform often personal stories of injustice experienced both on and off campus into change-oriented initiatives, and hold their institutions accountable (Linder et al., 2016; Ludden, 2014).

\section{Implications for Leadership Education}

Earlier in this article, we critiqued competency-based education, arguing that the leadership competencies (awareness, knowledge, and skills) developed by educators tend to fall short; the complexity of leadership gets reduced to a narrow set of characteristics that may (unwittingly) sustain the status quo rather than empower adaptive leadership. In this section, we describe what student leadership education can look like when leadership educators adopt a feminist perspective. In particular, we argue that consciousness-raising, one of central tenets of feminism, is essential for leadership development; it raises (self)awareness and cultivates critical consciousness (Ardovini, 2015; Stanley \& Wise, 1993). We delineate three particular applications of this consciousness-raising for: 1) leadership curriculum; 2) reflexivity of student leaders, and 3) leadership educators.

Consciousness-Raising of Leadership Curriculum. In order to develop students who will lead as agents of change, what should leadership education curriculum include? The content of the curriculum should still impart foundational knowledge (e.g., leadership theories); however, it must also incorporate "forward-thinking practice" (Sulpizio, 2014, p. 97). This means leadership educators will teach student leaders about the many conceptualizations of power and that leadership is not solely positional, but also collective. Students will understand "how structural imbalances in power produce real limits on the capacity of subordinate groups to exercise a sense of agency and struggle" (Giroux, 1993, p. 27). Individuals come to learn the challenges for adaptive leadership, and that for effective reform, "the entire system must be restructured, not just some of its parts" (Banks, 1995, p. 393). We also advocate for 'troubling' notions of who is a leader. Inviting a diversity of speakers to reflect all genders and amplify minoritized voices, to share their stories of leading change, being activists, and creating equitable organizations allows students to hear and learn from others, seeing what can be possible.

As the curriculum -- and student leaders' knowledge -- gets complicated, their opportunities to practice the skills needed to enact their knowledge is even more critical. Student leaders must have opportunities to "apprentice" activist work (Bisignani, 2014). Educators could identify an issue related to equity on campus or in the community which the students then research and address, through proposals for resolution or by serving as a consultant to an organization aiming to advance equity. Clark-Taylor, Mitchell, and Rich (2014) provided a helpful example in their description of a summer internship offered through the University of Rochester's Gender and Women's Studies program, which was explicitly designed to develop students' skills in feminist leadership and activism. Others argue for, or model through their practices, how to (re)design spaces that can develop activist orientations 
(Baumgardner \& Richards, 2005; Iverson \& James, 2014). One approach, rhetorical activism (Sowards \& Renegar, 2006), includes sharing stories and resisting stereotypes and labels.

An illustrative example can be found in the issue of sexual violence on campus. Students can, and do, engage in collaborative, empowered action through programming such as Take Back the Night; however, students could also engage in letter writing campaigns/petitions, where individuals organize their classmates and compose written correspondence addressed to campus and/or government officials regarding the limitations of policies and laws (Iverson, 2015). Such activist efforts within the curriculum could also mean creating small working groups in a leadership course committed to resolving specific campus issues related to gender such as underrepresentation of women in STEM (science, technology, engineering, and mathematics) or female students involvement in student government. Leadership educators need to consider how to utilize social media in their curriculum as an educational resource as it relates to activism and social change (Linder et al., 2016). Opportunities such as these allow students to develop and deploy privilege-cognizant knowledge, critical consciousness, and justice-oriented skills needed to take action in the larger community/society (Iverson, 2012; Linder, 2018).

Consciousness-Raising of Student Leaders. Inextricably linked to the development of curriculum that cultivates critical knowledge and skills (described above) is the need for critical (self)awareness. Kumagai and Lypson (2009) argued that competency frameworks must foster critical self-awareness, to yield critical consciousness about one's own identity and privileges. Such a consciousness involves a "reflective awareness of the differences in power and privilege and the inequities that are embedded in social relationships" (p. 783).

An important element of consciousness-raising is critical reflexivity -- a process of reflection through which one examines and unsettles one's assumptions and preconceptions, and how these affect decisions, experience, and actions (Cunliffe, 2009; Hertz, 1997; Warren, 2011). If an objective of applying feminism to leadership education is to address injustices and inequalities, and spurring students to become activists, student leaders must have opportunities to critically reflect on their own experiences and approaches to addressing said challenges in order to be able to take a stand in society. For example, students could be asked to write their autobiography as a way to begin to understand how they perceive actions and experiences and relate those to how they are as a leader (Densten \& Gray, 2001). Such reflections could help students recognize how their own views of leadership are shaped by gender role expectations (Haber-Curran \& Tillapaugh, 2017, p. 18). Journal reflections throughout a leadership course or program could also be used as a way to integrate learning and experience. Discussion questions could be posed that suggest situations college students may face and how they would respond as well as how it would make them feel, and students could be asked to share their stories with others in "brave" spaces (e.g., consciousness-raising groups) that "encourage taking risks" (Arao \& Clemens, 2013, p. 141). The idea of critical reflexivity allows students to build on previous leadership experiences and incorporate new learning about future experience as leaders.

Consciousness-Raising of Leadership Educators. Finally, little of the above recommendations will be realized if leadership educators -- those who develop the curriculum and advise the student leaders -- fail to explore their own assumptions about leadership. For instance, leadership educators must engage in the same reflexive activities that they assign their 
students. They must interrogate their assumptions and acceptance of socially constructed gender roles to the work they do, often unconsciously. They need to challenge themselves about what they believe and how those beliefs are reflected in how they perform their jobs. Leadership educators should review what voices are (and are not) incorporated in the readings they select for students. Much of the commonly used scholarship and literature about leadership has been written by men; leadership educators who are concerned about providing a balance of knowledge and experience to their students must challenge themselves to find writings from a variety of viewpoints from a variety of voices, including those of women and people of color. Leadership educators must also be willing to confront sexism when it occurs in their programs, addressing sexist comments and providing safe (and brave) spaces for students to explore what they know about gender identity and their acceptance of socially constructed views and to develop skills to challenge those views in themselves first and then in the larger community. This may not be an easy process for leadership educators and will require learning and self-exploration on the part of these professionals, which could be accomplished through attendance at conference sessions, reading, journaling, and departmental professional development activities designed to explore the social construction of gender. Although these shifts may present challenges, it is important for leadership educators to make these changes in their programs in order to contribute to students' leadership identity development.

\section{Future Research}

Future research should investigate the advantages and disadvantages of suggestions made in this article. For instance, how does identity matter? Inquiry is needed to understand the role our socially constructed understanding of gender plays in one's leadership journey, both for student leaders and for the educators who develop student leadership curriculum. Further, research should explore in what ways our theoretical argument does, or does not, transcend cultural boundaries. Finally, we are drawn to the assumption that feminist pedagogy lends itself to the approach to leadership education that we describe. However, research is needed to determine what pedagogical approaches, informed by what epistemological assumptions, contribute to certain outcomes (such as raised consciousness, activist orientations).

\section{Conclusions}

Leadership educators articulate a sense of urgency in the need to develop dynamic, resilient student leaders prepared to lead change on their college campuses and in their workplaces and communities (Komives, Lucas, \& McMahon, 2013). Some call for leadership development initiatives that will promote critical and creative thinking and develop the capacity for positive change; yet, these "needed attributes" (Coers, 2018, p. 2) must be more than a prescribed list of characteristics. In this paper, we have argued that deploying feminism as a theoretical strategy can develop in students the critically-conscious, adaptive leadership needed for socially just change. Note, we are not calling for feminist leadership, which could be misinterpreted as a characteristic one chooses to adopt, like being a charismatic leader, or could be relegated to particular disciplinary homes (i.e. women's studies) or certain student groups (i.e. student women's association). Rather this article aims to cross boundaries or borders that have framed the work of feminism and leadership, arguing that the field of leadership education needs feminism as a lens through which to frame initiatives for students. Application of a feminist lens 
will allow the focus of student leadership education to shift from an emphasis on positional, competency-based views of leaders to one that is more attuned to identities, voice, and taking action in an adaptive (not technical) fashion.

In conclusion, much can be done to educate college students and to encourage their development as leaders. Higher education needs to take a more deliberate role in preparing college students for experiences they may face on our campuses or in the workplace and society - stereotypes, discrimination, and inequity, for example. While we acknowledge this approach can be messy and risky, the core tenets of feminism can provide a framework for helping college students find their voice and lead positive change. We approach this article as a space for thinking in public, enabling our theorizing to be "susceptible to critical review and evaluation, and accessible for exchange and use" (Shulman, 1998, p. 5). We believe that by asking questions, or what Hutchings and Shulman (1999) called "going meta," we are extending an effort to improve the context of student leadership development programs. This "going meta" approach encourages us to question how and in what ways student leadership learning is occurring and critically consider ways of "advancing practice beyond it" (Hutchings \& Shulman, 1999, p. 13).

\section{References}

Aleman, M., \& Stephenson, J. (2012). Creating a consciousness of leadership: A case study of a university women's consciousness raising group. In E.L. Ruminski \& A.M. Holba (Eds.), Communicative understandings of women's leadership development (pp. 113-134). Lanham, MD: Lexington Books.

Allan, E. (2008). Policy discourses, gender and education: Constructing women's status. New York, NY: Routledge.

Allan, E. J., Gordon, S. P., \& Iverson, S. V. (2006). Re/thinking practices of power: The discursive framing of leadership in The Chronicle of Higher Education. The Review of Higher Education, 30(1), 41-68.

Allen, A. (1998, Winter). Rethinking power. Hypatia, 13(1), 21-40.

Arao, B., \& Clemens, K. (2013). From safe spaces to brave spaces: A new way to frame dialogue around diversity and social justice. In L.M. Landreman (Ed.), The art of effective facilitation: Reflections from social justice educators (pp. 135-150). Sterling, VA: Stylus Publishing.

Ardovini, J. (2015). Consciousness-Raising: A tool for feminist praxis in research and granting voice. Theory in Action, 8(1), 51-59.

Astin, A. W., \& Astin, H. S. (2000). Leadership reconsidered: Engaging higher education in social change. Battle Creek, MI: W. K. Kellogg Foundation. 
Astin, H., \& Leland, C. (1991). Women of influence, women of vision: A cross-generational study of leaders and change. San Francisco: Jossey-Bass Publishers.

Banks, J.A. (1995). Multicultural education and curriculum transformation. The Journal of Negro Education, 64(4), 390-400.

Bass, B.M. (1985). Leadership and performance beyond expectations. New York, NY: The Free Press.

Batliwala, S. (2001). Feminist leadership for social transformation: Clearing the conceptual cloud. CREA. Retrieved from http://web.creaworld.org/publications.asp.

Bauer-Wolf, J. (2018, March 15). Walkouts nationwide. Inside HigherEd. Retrieved from https://www.insidehighered.com/news/2018/03/15/college-students-join-gun-reformwalkout-nationwide

Baumgardner, J., \& Richards, A. (2005). Grassroots: A field guide for feminist activism. New York: Farrar, Straus and Giroux.

Bensimon, E., \& Neumann, A. (1993). Redesigning collegiate leadership: Teams and teamwork in higher education. Baltimore, MD: Johns Hopkins University Press.

Bisignani, D. (2014). Transgressing intellectual boundaries begins with transgressing physical ones: Feminist community engagement as activist-apprentice pedagogy. In S.V. Iverson, \& J.H. James (Eds.), Feminist community engagement: Achieving praxis (pp. 93-11). New York, NY: Palgrave.

Bolden, R., \& Gosling, J. (2006). Leadership competencies: Time to change the tune? Leadership, 2(2), 147-163.

Burns, J. M. (1978). Leadership. New York, NY: Harper \& Row.

Butler, B. (2014, March 5). "I, too am Harvard": Black students show they belong. The Washington Post. Retrieved from https://www.washingtonpost.com/blogs/she-thepeople/wp/2014/03/05/i-too-am-harvard-black-students-show-they-belong

Chemers, M.M. (1997). An integrative theory of leadership. Mahway, NJ: Lawrence Erlbaum Associates.

Chin, J. L. (2004). Feminist leadership: Feminist visions and diverse voices. Psychology of Women Quarterly, 28, 1-8.

Chin, J. L., Lott, B., Rice, J., \& Sanchez-Hucles, J. (Eds.). (2008). Women and leadership: Transforming visions and diverse voices. Malden, MA: Blackwell Publishing. 
Clance, P. R., \& Imes, S. (1978). The imposter phenomenon in high-achieving women: Dynamics and therapeutic intervention. Psychotherapy Theory, Research, and Practice, 15(3), 1-8.

Clark-Taylor, A., Mitchell, Q., \& Rich, K. (2014). Moving from service to action: The Rocxxy summer internship in feminism activism and leadership. In S.V. Iverson \& J.H. James (Eds.), Feminist community engagement: Achieving praxis (pp. 155-173). New York, NY: Palgrave.

Coers, N.J. (2018). Cultivating visionary leaders to transform our world. Journal of Leadership Education, 17(1), 1-6.

Conger, J. A. (1991). Inspiring others: The language of leadership. Academy of Management Perspectives, 5(1), 31-45.

Conger, J. A., \& Ready, D. A. (2004). Rethinking leadership competencies. Leader to Leader, 41-47.

Cunliffe, A.L. (2009). The philosopher leader: On relationalism, ethics and reflexivity - A critical perspective to teaching leadership. Management Learning, 40(1), 87-101.

Cress, C. M., Astin, H. S., Zimmerman-Oster, K., \& Burkhardt, C. J. (2001). Developmental outcomes of college students' involvement in leadership activities. Journal of College Student Development, 42(1), 15-27.

Debebe, G., \& Reinert, K. A. (2014). Leading with our whole selves: A multiple identity approach to leadership development. In M. Miville \& A. Ferguson (Eds.), Handbook on race-ethnicity and gender in psychology (pp. 271-293). New York, NY: Springer.

Denston, I. L., \& Gray, J. H. (2001). Leadership development and reflection: What is the connection? The International Journal of Educational Management, 15(3), 119-124.

DiPaolo, D. G. (2008). Echoes of leadership education: Reflections on failure, forgetting, and our future. Journal of Leadership Education, 7(1), 77-91.

Drescher, M.A., Korsgaard, M.A., Welpe, I.M., Picot, A., \& Wigand, R.T. (2014). The dynamics of shared leadership: Building trust and enhancing performance. Journal of Applied Psychology, 99(5), 771-783.

Dugan, J.P. (2017). Leadership theory: Cultivating critical perspectives. San Francisco: JosseyBass.

Dugan, J. P., Komives, S. R., \& Segar, T. C. (2008). College students capacity for socially responsible leadership: Understanding norms and influences of race, gender, and sexual orientation. NASPA Journal, 45(4), 475-500. 
Eagly, A. H., \& Carli, L. L. (2007). Through the labyrinth: The truth about how women become leaders. Boston, MA: Harvard Business School Press.

Eddy, P., Ward, K., \& Khwaja, T. (Eds.) (2017). Critical approaches to women and gender in higher education. New York, NY: Palgrave.

Fine, M. G. (2009). Women leaders' discursive constructions of leadership. Women's Studies in Communication, 32(2), 180-202.

Gautney, H. (2011, October 10). What is Occupy Wall Street? The history of leaderless movements. Washington Post. Retrieved from http://www.washingtonpost.com

Giroux, H. A. (1993). The politics of insurgent multiculturalism in the era of the Los Angeles uprising. The Journal of the Midwest Modern Language Association, 26(1), 12-30.

Gluckman, N., Read, B., Mangan, K., \& Quilantan, B. (2017, November 13). Sexual harassment and assault in higher education: What's happened since Weinstein. The Chronicle of Higher Education. Retrieved from http://www.chronicle.com

Haber-Curran, P., \& Sulpizio, L. (2017, Summer). Student leadership development for girls and young women. New Directions for Student Leadership, 154, 33-46.

Haber-Curran, P., \& Tillapaugh, D. (2017, Summer). Gender and student leadership: A critical examination. New Directions for Student Leadership, 154, 11-22.

Heifetz, R.A. (1994). Leadership without easy answers. Cambridge, MA: Harvard University Press.

Hertz, R. (1997). Reflexivity and voice. Thousand Oaks, CA: Sage.

Hesse-Biber, S. N. (Ed.). (2011). Handbook of feminist research: Theory and praxis. Thousand Oaks, CA: SAGE publications.

Hollenbeck, G. P., McCall, Jr., M. W., \& Silzer, R. F. (2006). Leadership competency models. The Leadership Quarterly, 17, 398-413.

hooks, b. (1994). Teaching to transgress. New York, NY: Routledge.

Hutchings, P., \& Shulman, L. (1999). The scholarship of teaching: New elaborations, new developments. Change: The Magazine of Higher Learning, 31(5), 10-15.

Iverson, S.V. (2015). The risky subject: A policy discourse analysis of sexual assault policies in higher education. In S. C. Wooten \& R. W. Mitchell (Eds.), The crisis of campus sexual violence: Critical perspectives on prevention and response (pp. 15-32). New York, NY: Routledge. 
Iverson, S.V. (2012). Multicultural competence for doing social justice: Expanding our awareness, knowledge, and skills. Journal of Critical Thought and Praxis, 1(1), 63-87.

Iverson, S.V. (2007). Teaching leaders to mobilize adaptive work. Academic Exchange Quarterly, 11(2), 102-106.

Iverson, S.V., Allan, E.J., \& Gordon, S.P. (2017). Constructing the double bind: The discursive framing of gendered images of leadership in The Chronicle of Higher Education. In J. Storberg-Walker \& P. Haber-Curran (Eds.), Theorizing women and leadership: New insights \& contributions from multiple perspectives (pp. 51-68). Charlotte, NC: Information Age Publishing.

Iverson, S.V., \& James, J.H. (Eds.). (2014). Feminist community engagement: Achieving praxis. New York, NY: Palgrave.

Keohane, N.O. (2014). Leadership out front and behind the scenes: Young women's ambitions for leadership today. In K.A. Longman \& S.R. Madsen (Eds.), Women \& leadership in higher education (pp. 41-55). Charlotte, NC: Information Age Publishing, Inc.

Kezar, A., Carducci, R., \& Contreras-McGavin, M. (2006). Rethinking the "L" word in higher education: The revolution of research on leadership. ASHE HIgher Education Report, 31(6). San Francisco: Jossey-Bass.

Kezar, A., \& Lester, J. (2011). Enhancing campus capacity for leadership. Stanford, CA: Stanford University Press.

Klofsted, C.A., Anderson, R.C., \& Peters, S. (2012). Sounds like a winner: Voice pitch influences perception of leadership capacity in both men and women. Proceedings of the Royal Society of London B: Biological Sciences. DOI: 10.1098/rspb.2012.0311

Komives, S. R., Lucas, N., \& McMahon, T. R. (2013). Exploring leadership: For college students who want to make a difference ( ${ }^{\text {rd }}$ ed.). San Francisco, CA: Jossey-Bass.

Komives, S. R., Wagner, W., \& Associates. (2009). Leadership for a better world: Understanding the social change model of leadership. San Francisco,CA: Jossey-Bass.

Kouzes, J. M., \& Posner, B. Z. (2008). The student leadership challenge: Five practices for exemplary leaders. San Francisco, CA: Jossey-Bass.

Kumagai, A.K., \& Lypson, M.L. (2009). Beyond cultural competence: Critical consciousness, social justice, and multicultural education. Academic Medicine, 84(6), 782-7.

Linder, C. (2018). Sexual violence on campus: Power-conscious approaches to awareness, prevention, and response (Great debates in higher education). Bingley, United Kingdom: Emerald Publishing. 
Linder, C., Myers, J. S., Riggle, C., \& Lacy, M. (2016). From margins to mainstream: Social media as a tool for campus sexual violence activism. Journal of Diversity in Higher Education, 9(3), 231-244.

Lipman-Blumen, J. (1992). Connective leadership: Female leadership styles in the $21^{\text {st }}$-century workplace. Sociological Perspectives, 35(1), 183-203.

Ludden, J. (2014, August 26). Student activists keep pressure on campus sexual assault. National Public Radio. Retrieved from http://www.npr.org/2014/ 08/26/343352075/studentactivists-keep-sexual- assault-issues-in-the-spotlight

Madsen, S. R. (Ed.). (2017). Handbook of Research on Gender and Leadership. Northhampton, MA: Edward Elgar Publishing.

McKenzie. B.L. (2015). Leadership identity development of traditional-aged female undergraduate college students: A grounded theory (Unpublished doctoral dissertation). Kent State University, Kent, $\mathrm{OH}$.

McKenzie, B. (2014). Student leadership competencies. Concepts \& Connections: A Publication for Leadership Educators, 20 (1), 23-26.

McKenzie, B.L., \& Iverson, S.V. (2017). Changing views of self-as-leader: What female college students tell us. In P. Eddy, K. Ward, \& T. Khwaja (Eds.), Critical approaches to women and gender in higher education (pp. 277-297). New York, NY: Palgrave.

Meyerson, D., \& Tompkins, M. (2007). Tempered radicals as institutional change agents: The case of advancing gender equity at the University of Michigan. Harvard Journal of Law \& Gender, 30, 303-322.

Northouse, P.G. (2016). Leadership: Theory and practice (7th ed.). Los Angeles, CA: SAGE.

Owen, J.E. (2015, Spring). Transforming leadership development for significant learning. New Directions for Student Leadership, 145, 7-17.

Posner, B. Z. (2009, September/October). A longitudinal study examining changes in students' behavior. Journal of College Student Development, 50, 551-563.

Rhode, D. L. (2016). Women and leadership. New York, NY: Oxford University Press.

Roberts, D.C. (2007). Deeper learning in leadership: Helping college students find the potential within. San Francisco, CA: John Wiley \& Sons.

Ross, S. R., Stewart, J., Mugge, M., \& Fultz, B. (2001). The imposter phenomenon, achievement disposition and the five factor model. Personality and Individual Differences, 31(8), 1347-1355. 
Rosser-Mims, D. (2010). Black feminism: An epistemological framework for exploring how race and gender impact Black women's leadership development. Advancing Women in Leadership, 30(15) 2-10.

Seemiller, C., \& Murray, T. (2013). The common language of leadership. Journal of Leadership Studies, 7(1), 33-45.

Shertzer, J. E., \& Schuh, J. H. (2004). College student perceptions of leadership: Empowering and constraining beliefs. NASPA Journal, 42, 111-131.

Shulman, L.S. (1998). Course anatomy: The dissection and analysis of knowledge through teaching. In P. Hutchings (Ed.), The course portfolio: How faculty can examine their teaching to advance practice and improve student learning (pp. 5-12). Washington, DC: American Association for Higher Education.

Sowards, S. K., \& Renegar, V. R. (2006). Reconceptualizing rhetorical activism in contemporary feminist contexts. The Howard Journal of Communications, 17, 57-74. doi:10.1080/10646170500487996

Spelman, E. V. (1998). Inessential woman: Problems of exclusion in feminist thought. Boston, MA: Beacon Press.

Stanley, L., \& Wise, S. (1993). Breaking out again: Feminist epistemology and ontology. New York, NY: Routledge.

Storberg-Walker, J., \& Haber-Curran, P. (Eds.) (2017). Theorizing women and leadership: New insights \& contributions from multiple perspectives. Charlotte, NC: Information Age Publishing.

Sulpizio, L.L. (2014). Developing women's leadership: An innovative and unique approach to raising leadership capacity. In K.A. Longman, \& S.R. Madsen (Eds.), Women and leadership in higher education (pp. 97-116). Charlotte, NC: IAP-Information Age Publishing.

Thurber, F., \& Zimmerman, E. (2002). An evolving feminist leadership model for art education. Studies in Art Education, 44(1), 5-27.

Tillapaugh, D., Mitchell, Jr., D., \& Soria, K.M. (2017). Considering gender and student leadership through the lens of intersectionality. New Directions for Student Leadership, 154, 23-32.

Tong, R. P. (2016). Feminist thought: A more comprehensive introduction (4th ed.). Boulder, CO: Westview Press.

Warren, J. T. (2011). Reflexive teaching: Toward critical autoethnographic practices of/in/on pedagogy. Cultural Studies? Critical Methodologies, 11(2), 139-144. 


\section{Author Biographies}

Susan V. Iverson, Ed.D., is Professor of Higher Education Leadership, and Director of the EdD Program, at Manhattanville College. Iverson's research interests include equity, diversity, status of women, leadership in higher education. Iverson earned her doctorate in higher educational leadership, with a concentration in women's studies, from the University of Maine.

Brenda L. McKenzie, Ph.D., is a Senior Lecturer in Higher Education Administration at Vanderbilt University. Her research interests includes college student leadership development, women and leadership, and the socialization and professional identity development of higher education/student affairs graduate students. Dr. McKenzie received her doctorate in Higher Education Administration from Kent State University. Brenda.1.mckenzie@ vanderbilt.edu

Malina Halman is the Assistant Director of the Office of Academic Services at Vanderbilt University's Peabody College of Education and Human Development. Her research interests include the ways in which media, community, and student affairs programming influence identity development and promote equity. Malina.c.halman@ vanderbilt.edu 